\title{
Population and Family Studies of Three Disease-related Polymorphic Genes in Systemic Lupus Erythematosus
}

\author{
De-Feng Huang, ${ }^{\star}$ Katherine A. Siminovitch, ${ }^{\S}$ Xiao-Yuan Liu, * Tsaiwei Olee, * Nancy J. Olsen," Charles Berry, \\ Dennis A. Carson, ${ }^{* \star \star}$ and Pojen P. Chen ${ }^{* *}$ \\ *Departments of Medicine and Pathology, University of California, San Diego, La Jolla, California 92093-0663; **Department of \\ Molecular and Experimental Medicine, The Scripps Research Institute, La Jolla, California 92037; ${ }^{\ddagger}$ Department of Medicine, Veterans \\ General Hospital-Taipei, Taiwan; ${ }^{8}$ Departments of Medicine, Immunology and Molecular and Medical Genetics, University of Toronto, \\ Toronto, Ontario M5T 2S8, Canada; "Department of Medicine, Vanderbilt University, Nashville, Tennessee 37232; and 'Departments of \\ Family and Preventive Medicine, University of California, San Diego, La Jolla, California 92093
}

\begin{abstract}
The contribution to systemic lupus erythematosus (SLE) of three lupus-associated polymorphisms (involving the $\mathrm{C4A}^{2}$ complement component, Humhv3005 and the $T$ cell antigen receptor alpha chain gene) are investigated in 81 individuals from 14 multiplex SLE families, 41 unrelated lupus patients, and 88 unrelated healthy controls. The results show a strong association between C4A deletion and SLE in these families. While the current study confirms the previously reported association between hv3005 deletion and sporadic SLE, the study fails to support this association in familial SLE patients. Moreover, no correlation is detected between the occurrence of hv3005 deletion and C4A null alleles in lupus patients, suggesting that the effects of these genetic polymorphisms on predisposition to lupus are independent. The previously reported lupus-associated $T$ cell receptor (TCR) $\alpha$ chain polymorphism is not detected in any of the individuals studied here. The combined data suggest that $\mathrm{C} 4 \mathrm{~A}$ null alleles predispose strongly to development of lupus, whereas the influence of hv3005 deletion is relatively weak. The results also suggest that contributions of weak susceptibility genes such as hv3005 to disease predisposition may be obscured by the effects of stronger genetic factors and thus need to be examined in patients lacking these factors. $(J$. Clin. Invest. 1995. 95:1766-1772.) Key words: autoantibodies - C4A deletion - Ig $V$ genes $-R F L P \cdot T$ cell receptor genes
\end{abstract}

\section{Introduction}

Systemic lupus erythematosus (SLE) is associated with formation of multiple autoantibodies and recurrent inflammation of various organ systems (1). While the cause of SLE is not

K. A. Siminovitch is a Career Scientist of the Ontario Ministry of Health and a Research Scientist of the Arthritis Society of Canada.

Address correspondence to Dr. Pojen P. Chen, Department of Medicine, 0663, University of California, San Diego, CA 92093. Phone: 619534-5410; FAX: 619-534-5399.

Received for publication 29 August 1994 and in revised form 29 November 1994.

J. Clin. Invest.

(c) The American Society for Clinical Investigation, Inc.

0021-9738/95/04/1766/07 \$2.00

Volume 95, April 1995, 1766-1772 known, epidemiologic and genetic data suggest that expression of this disease reflects an interplay between genetic and environmental factors. As aberrant immune function represents the most characteristic phenotypic abnormality in lupus patients, logical candidate susceptibility genes for this condition are those encoding molecules important to normal immunity. Among these, the major histocompatibility complex (MHC) ${ }^{1}$ class II genes have been particularly well studied in relation to lupus and, at least in Caucasians, associations of this disease with HLA-DR3 and to a lesser extent, DR2 have been reported (2). However, these MHC disease associations are not apparent in all populations studied and vary among different subsets of lupus patients. Thus the class II alleles do not entirely account for genetic predisposition to lupus and the existence of other lupus-susceptibility genes appears likely.

In recent years, genetic studies of lupus patients have revealed several additional candidate genes for SLE. These include, for example, the genes encoding two early complement components, C2 and C4 (2, 3). In one reported study, $\sim 40 \%$ of persons with complete deficiency of the second complement component (i.e., homozygous deletion of the $\mathrm{C} 2$ gene) had SLE; and $\sim 44 \%$ of SLE patients lacked at least one copy of their C4A complement gene, in contrast to $13 \%$ of the normal population (3). The complement deficiencies may predispose to SLE by impairing immune complex clearance, or increasing risk of exposure to a triggering agent. Along similar lines, specific Ig and T cell antigen receptor (TCR) genotypes have also been recently invoked as possible lupus susceptibility genes. For example, one group reported an association of lupus with a restriction fragment length polymorphism (RFLP) at the T cell antigen receptor (TCR) alpha chain constant $(\mathrm{C} \alpha)$ region (4).

Previously, we described an Ig heavy chain variable region (Vh) gene polymorphism involving the closely related Vh3 germline genes, Humhv3005 and 1.9III. Our data revealed the association of lupus with the complete absence of a 9.4-kb RFLP band detected with an hv3005 gene probe (5). Sequence analysis of the hv3005 and related Vh3 genes in individuals with various hv3005-RFLP patterns revealed the absence of hv3005 and/or hv3005-like genes in 8/9 individuals with the 9.4-kb deletions; by contrast, $1.9 \mathrm{III}$ and/or 1.9III-like genes were present in these individuals (6). Taken together, the data

1. Abbreviations used in this paper: C4A, the A isotype of the 4th component of the complement system; TCR, T cell antigen receptor; $\mathrm{V}$ gene, variable region gene. 
suggest an increased frequency of hv3005-like gene deletion among lupus patients compared with healthy controls $(5,6)$.

These observations are consistent with the contention that multiple genes are involved in the susceptibility to lupus. However, it is not clear how these genes interact with one another and, in particular, whether their effects on lupus predisposition are independent, additive and/or equal. To address these issues we investigated 14 multicase lupus families as well as unrelated lupus patients with respect to three loci implicated in susceptibility to SLE: the C4A, hv3005 and TCR C $\alpha$ loci. We find that gender and C4A deletion play an important role in expression of SLE, while the influence of hv3005 deletion is weak. As TCR C $\alpha$ polymorphisms are not detected in this group, the contribution of this gene to susceptibility could not be addressed. Our findings suggest that the effects of a weak susceptibility factor, such as the hv3005 deletion, on disease predisposition may become more obvious in the absence of strong disease susceptibility factors. These results emphasize the complexity inherent to identifying the genetic basis of lupus and the importance of addressing this issue in the context of both familial and sporadic cases.

\section{Methods}

Patients and normal donors. The study group included 41 unrelated Caucasian lupus patients and 88 healthy unrelated Caucasian controls. Fourteen multicase SLE families (at least two members affected) including 48 unaffected and 33 affected individuals were also studied. The subjects were ascertained in Toronto, Canada and four U. S. cities. All SLE patients fulfilled the American College of Rheumatology revised criteria for SLE (7).

Genomic DNA and southern blot analyses. Genomic DNA was extracted from peripheral blood leukocytes, and was digested with the indicated restriction enzymes. The lysates were loaded into wells of a $0.7 \%$ agarose gel. After electrophoresis and transfer of DNA to nitrocellulose, the blots were hybridized with the indicated probes. Hybridization was done in $5 \times \mathrm{SSC}(1 \times \mathrm{SSC}=0.15 \mathrm{M} \mathrm{NaCl} / 0.015 \mathrm{M}$ sodium citrate, $\mathrm{pH} 7.0$ ) at $65^{\circ} \mathrm{C}$, followed by washing twice in $0.1 \times$ SSC at $65^{\circ} \mathrm{C}$.

The probes used are: (a) Hv3005/P1, a 466 basepair (bp) PstI fragment located $\sim 1 \mathrm{~kb}$ upstream of the $\mathrm{Hv} 3005$ gene (5); (b) C4A, a 900-bp KpnI/PstI fragment from the 5' end of the C4A gene (kindly provided by Dr. David D. Chaplin, Washington University, St. Louis, MO) (3); (e) TCR $\alpha$ chain C $\alpha 1$, a 267-bp fragment (corresponding to nucleotides from 273 to 539 in the first exon) (8); (d) TCR $\alpha$ chain $\mathrm{C} \alpha 2$, a 310-bp fragment (corresponding to nucleotides from 2411 to 2720 , encompassing the second exon and a segment of the downstream intron) (8). The TCR probes were amplified by polymerase chain reaction (PCR) from the genomic DNA of the Y79 retinoblastoma (9), using the $5^{\prime}$ TCR- $\alpha$-C1U1s primer (5'-ATATC-CAGAA-CCCTGACCCT-3') and the $3^{\prime}$ TCR-a-C1D1c primer (5'-TGGGG-AAGAAGGTGT-CTTCT- $3^{\prime}$ ) for TCR C $\alpha 1$, and the $5^{\prime}$ C2U1s (5'-GTTCCTGTGA-TGTCA-AGCTG-3') primer and the $3^{\prime}$ C2D1c ( $5^{\prime}$-AAGGAATACA-GAGGC-CTAGG-3') primer for C $\alpha 2$. A PstI site was added to the 5' end of each primer. The amplified DNA was cloned into pUC19 and sequenced to verify that both amplified DNA fragments were $100 \%$ identical to the reported human TCR C $\alpha$ sequences (8).

Asymmetric amplification and direct sequencing. Each DNA sample was amplified simultaneously in two separate reaction mixtures, each consisting of $1 \mu \mathrm{g}$ of genomic DNA, and 20 pmoles of hv3005D2c, with either 1 or 2 pmoles of hv3005U1s as the limiting primer. Hv3005U1s and hv3005D2c correspond respectively to nucleotide positions from -135 to -116 , and from 488 to 467 (6). The mixtures were incubated for 45 cycles; each consisted of $1.5^{\prime}$ annealing at $55^{\circ} \mathrm{C}, 2^{\prime}$ elongation at $72^{\circ} \mathrm{C}$ and $1^{\prime}$ dissociation at $95^{\circ} \mathrm{C}$. The amplified DNA was extracted once with TE-saturated phenol, precipitated, resuspended in Tris-EDTA buffer, and sequenced with the limiting primer.

Statistical analyses. The association of hv3005 deletion and C4A null allele with SLE in the multicase families was examined by the Mantel-Haenszel $\chi^{2}$ test with one degree of freedom $(10,11)$. This test calculates the summary relative risk as a weighted average of the separate relative risk from all strata (in a way that eliminates confounding by the stratified variable), and determines whether the summary relative risk differs significantly from the no-association relative risk of 1.0. The interactions of hv3005 deletion, C4A null allele and gender were tested by the likelihood ratio chi-square statistic for a log-linear model of a three-way table of counts (10). The association between hv3005 deletion and SLE in unrelated individuals was also tested by the MantelHaenszel $\chi^{2}$ test with one degree of freedom, taking account of the different rates of SLE among males and females. In addition, the association between hv3005 deletion and SLE in unrelated males was determined by Fisher's exact test, due to the small number of male patients (i.e., 5).

\section{Results}

Family and population study of the humhv3005/p1 RFLP in $S L E$. To determine whether the genetic contribution of SLE might be more easily elucidated by analysis of familial rather than sporadic cases of SLE, we studied the members of 14 families with respect to RFLP genotypes of the hv3005 set of Ig $\mathrm{V}$ genes. DNA samples from patients and healthy relatives were digested with EcoR1, and their hv3005 genotypes examined by Southern blot analysis using the hv3005/P1 genomic DNA probe. As can be seen in Tables I and II, the 9.4-kb deletion occurred in $8 / 33(24 \%)$ patients, as well as in $10 / 47$ (21\%) normal relatives ( the genotype of one DNA sample from a normal male relative could not be determined after repeated trials).

Direct sequence analysis of hv3005 and related Vh3 genes in selected individuals had revealed that $8 / 9$ individuals with the 9.4-kb deletion, were missing hv3005-like Vh gene elements and possessed only 1.9III-like genes (6). Accordingly, we amplified and sequenced hv3005- and 1.9III-like genes from 13 of 18 subjects who lacked the 9.4-kb band (Table I). The results showed that all 13 individuals had 1.9III-like genes, but not the hv3005-like genes (data not shown). These data indicate that most individuals lacking the 9.4-kb restriction fragments have a complete deletion of the hv3005-like genes, including at least the hv3005 and $3 \mathrm{~d} 216$ (or 56P1) Vh3 germline genes (12).

Gender has long been recognized as a potentially key factor in the development of SLE, with 90\% of SLE patients being female (13). Therefore, the results of hv3005 genotype studies were analyzed by considering female and male individuals separately. There were no male SLE patients in the 14 families. Among female patients and unaffected relatives, the frequencies of the 9.4-kb deletion were 8/33 (24\%) and 5/25 (20\%), respectively. Therefore, even when gender was taken into consideration, these studies failed to show an association between hv3005 deletion and lupus among familial SLE patients.

Previously, we studied 22 unrelated SLE patients and 42 unrelated normals, and found the 9.4-kb band to be absent in 6 patients (27\%) and 2 normals (5\%), yielding a $P$ value of 0.03 (5). As the familial data contrasted with previous observation in non-familial SLE patients, we performed further studies of hv3005 genotypes in unrelated patients and normal controls. To 


\begin{tabular}{|c|c|c|c|c|c|c|c|c|c|c|c|c|c|c|c|c|c|c|c|}
\hline \multirow[b]{2}{*}{ Family } & \multirow[b]{2}{*}{ No } & \multirow[b]{2}{*}{ Normal } & \multirow[b]{2}{*}{ SLE } & \multirow[b]{2}{*}{ Sex } & \multirow[b]{2}{*}{$\begin{array}{l}\text { hv3005 } \\
9.4 \mathrm{~kb}^{\ddagger}\end{array}$} & \multirow[b]{2}{*}{$\begin{array}{l}\text { C4A } \\
\text { gene* }^{*}\end{array}$} & \multicolumn{3}{|c|}{ C4/HindIII RFLP* } & \multirow[b]{2}{*}{ Family } & \multirow[b]{2}{*}{ No } & \multirow[b]{2}{*}{ Normal } & \multirow[b]{2}{*}{ SLE } & \multirow[b]{2}{*}{ Sex } & \multirow[b]{2}{*}{$\begin{array}{l}\text { hv3005 } \\
9.4 \mathrm{~kb}^{\ddagger}\end{array}$} & \multirow[b]{2}{*}{$\begin{array}{c}\text { C4A } \\
\text { gene* }\end{array}$} & \multicolumn{3}{|c|}{ C4/HindIII RFLP* } \\
\hline & & & & & & & $\begin{array}{l}26 \\
\text { kb }\end{array}$ & $\begin{array}{l}15 \\
\mathbf{k b}\end{array}$ & $\begin{array}{l}8.5 \\
\mathbf{k b}\end{array}$ & & & & & & & & $\begin{array}{l}26 \\
\mathrm{~kb}\end{array}$ & $\begin{array}{l}15 \\
\mathrm{~kb}\end{array}$ & $\begin{array}{l}8.5 \\
\mathrm{~kb}\end{array}$ \\
\hline I & 1 & & Al & f & + & $-1^{*}$ & + & + & + & VIII & 39 & $\mathrm{H} 1$ & & $\mathrm{~m}$ & - & + & + & + & - \\
\hline & 2 & & A2 & $\mathrm{f}$ & + & + & + & + & - & & 40 & & $\mathrm{H} 2$ & f & + & -1 & + & + & + \\
\hline & & & & & & & & & & & 41 & & H3 & f & + & -1 & + & + & + \\
\hline II & 3 & & B1 & f &,$- \mathrm{s}^{\ddagger}$ & + & + & + & - & & 42 & $\mathrm{H} 4$ & & $\mathrm{~m}$ & + & + & + & + & - \\
\hline & 4 & & B2 & f &,$- \mathrm{s}$ & + & + & + & - & & 43 & & H5 & $\mathrm{f}$ & + & + & + & + & - \\
\hline & 5 & B3 & & f & + & + & + & + & - & & 44 & H6 & & f & + & -1 & + & + & + \\
\hline & 6 & & B4 & $\mathrm{f}$ & - & ND* & ND & ND & ND & & 45 & $\mathrm{H} 7$ & & $\mathrm{~m}$ &,$- \mathrm{s}$ & + & + & + & - \\
\hline III & 7 & $\mathrm{C} 1$ & & $\mathrm{~m}$ & + & + & + & + & - & & 46 & $\mathrm{H} 8$ & & $\mathbf{m}$ & + & + & + & + & - \\
\hline & 8 & $\mathrm{C} 2$ & & $\mathrm{f}$ & + & -1 & + & + & + & IX & 47 & I1 & & $\mathrm{m}$ & + & + & + & + & - \\
\hline & 9 & & C3 & f & + & $-2 *$ & - & - & + & & 48 & & I2 & f & + & + & + & + & - \\
\hline & 10 & & $\mathrm{C} 4$ & $\mathrm{f}$ & + & -2 & - & - & + & & 49 & & I3 & f & + & + & + & + & - \\
\hline & 11 & C5 & & f & + & + & + & + & - & & 50 & & I4 & f & + & + & + & + & - \\
\hline & & & & & & & & & & & 51 & I5 & & f & + & + & + & + & - \\
\hline IV & 12 & & D1 & f & + & -2 & - & - & + & & 52 & I6 & & $\mathrm{m}$ & + & + & + & + & - \\
\hline & 13 & D2 & & $\mathrm{m}$ & $?$ & -1 & + & + & + & & & & & & & & & & \\
\hline & 14 & D3 & & f & + & + & + & + & - & IX & 53 & 17 & & f & + & + & + & + & - \\
\hline & 15 & & D4 & f & + & + & + & + & - & $\mathrm{X}$ & 54 & $\mathrm{~J} 1$ & & $\mathrm{~m}$ & + & + & + & + & - \\
\hline & 16 & D5 & & $\mathbf{f}$ & + & + & + & + & - & & 55 & & $\mathrm{~J} 2$ & f & + & -1 & + & + & + \\
\hline & 17 & & D6 & $\mathrm{f}$ & + & + & + & + & - & & 56 & & J3 & $\mathrm{m}$ & + & + & + & + & - \\
\hline & & & & & & & & & & & 57 & & J5 & $f$ & + & -1 & + & + & + \\
\hline V & 18 & & E1 & f &,$- \mathrm{s}$ & -1 & + & $\begin{array}{l}+ \\
+\end{array}$ & $\begin{array}{l}+ \\
+\end{array}$ & & 58 & J6 & & f & + & + & + & + & - \\
\hline & 19 & E2 & & $\mathbf{m}$ & - & -1 & + & $\begin{array}{l}+ \\
+\end{array}$ & $\begin{array}{l}+ \\
+\end{array}$ & XI & 59 & K1 & & $\mathrm{m}$ &,$- \mathrm{s}$ & -1 & + & + & + \\
\hline & 20 & & E3 & f &,$- \mathrm{s}$ & -1 & + & + & & & & $K^{1}$ & & Im & + & + & 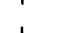 & 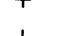 & \\
\hline & 21 & E4 & & $\mathbf{f}$ & - & -1 & + & + & + & & 60 & K2 & & $\mathrm{m}$ & $\begin{array}{l}+ \\
+\end{array}$ & $\begin{array}{l}+ \\
+\end{array}$ & + & + & - \\
\hline & & & & & & & & & & & 61 & & K3 & f & + & + & + & + & - \\
\hline VI & 22 & F1 & & f & + & + & + & + & - & & 62 & K4 & & f & - & + & + & + & - \\
\hline & 23 & $\mathrm{~F} 2$ & & f & + & + & + & + & - & & 63 & K5 & & $\mathbf{m}$ & + & + & + & + & - \\
\hline & 24 & & F3 & $\mathrm{f}$ & + & + & + & + & - & & 64 & & K6 & f &,$- \mathrm{s}$ & -1 & + & + & + \\
\hline & 25 & & $\mathrm{~F} 4$ & $\mathrm{f}$ & + & + & + & + & - & & 65 & K7 & & $\mathrm{m}$ & + & -1 & + & + & + \\
\hline & 26 & F5 & & $\mathbf{m}$ & + & + & + & + & - & & 66 & K8 & & f &,$- \mathrm{s}$ & + & + & + & - \\
\hline & 27 & F6 & & f & + & + & + & + & - & & 67 & K9 & & $\mathrm{f}$ & + & + & + & + & - \\
\hline & 28 & F7 & & f & + & + & + & + & - & & 68 & & K10 & $f$ & + & -1 & + & + & + \\
\hline & 29 & F8 & & f & + & + & + & + & - & & 69 & K11 & & $\mathbf{m}$ & + & + & + & + & - \\
\hline & 30 & F9 & & $\mathrm{m}$ & + & + & + & + & - & XII & 70 & L1 & & $\mathbf{m}$ & + & ND & ND & ND & ND \\
\hline & 31 & F10 & & f & + & + & + & + & - & & 71 & & L2 & f & + & -1 & + & + & + \\
\hline & 32 & F11 & & f & + & + & + & + & - & & 72 & L3 & & $\mathrm{m}$ &,$- \mathrm{s}$ & -1 & + & + & + \\
\hline & 33 & $\mathrm{~F} 12$ & & f & + & -1 & + & + & + & & 73 & & $\mathrm{~L} 4$ & f & + & -1 & + & + & + \\
\hline VII & 34 & G1 & & f & + & + & + & + & - & & 74 & L5 & & f & + & -1 & + & + & + \\
\hline & 35 & G2 & & $\mathrm{m}$ & + & -1 & + & + & + & & 75 & L6 & & $\mathrm{m}$ & + & + & + & + & - \\
\hline & 36 & G3 & & f &,$- \mathrm{s}$ & + & + & + & - & XIII & 76 & M1 & & $\mathrm{m}$ & + & + & + & + & - \\
\hline & 37 & & G4 & f &,$- \mathrm{s}$ & -1 & + & + & + & & 77 & & M2 & f & + & -1 & + & + & + \\
\hline & 38 & & G5 & f &,$- \mathrm{s}$ & -1 & + & + & + & & 78 & & M3 & f & + & -1 & + & + & + \\
\hline & & & & & & & & & & & 79 & M4 & & $\mathbf{f}$ &,$- \mathrm{s}$ & -1 & + & + & + \\
\hline & & & & & & & & & & XIV & 80 & & N1 & f & + & + & + & + & - \\
\hline & & & & & & & & & & & 81 & & N2 & f & + & + & + & + & - \\
\hline
\end{tabular}

* The C4A genotype was determined by hybridizing the HindIII-digested DNA with a C4A probe. The 26-, 15-, and 8.5-kb bands represent, respectively, the $\mathrm{C} 4 \mathrm{~B}$, the $\mathrm{C} 4 \mathrm{~A}$ and a $\mathrm{C} 4 \mathrm{~A}-\mathrm{C} 4 \mathrm{~B}$ hybrid genes (due to a deletion of most of the $\mathrm{C} 4 \mathrm{~A}$ gene); + and - denote, respectively, presence and absence. In the column of "C4A gene," -1 and -2 denote, respectively, the deletion of 1 and 2 copies of the C4A gene. ND indicates not determined. " The hv3005 genotype was determined by hybridizing the EcoRI-digested DNA with hv3005/P1; the absence of the 9.4-kb band generally indicates a complete deletion of all hv3005-like genes. The deletion was confirmed by specific amplification and direct sequencing of the hv3005 like-genes in 13 of the 18 individuals, as indicated by "s." 
Table II. Statistical Analyses of hv3005 and C4A Deletions in SLE

\begin{tabular}{|c|c|c|c|c|c|c|c|c|}
\hline \multirow[b]{2}{*}{ Study } & \multirow[b]{2}{*}{ Group } & \multicolumn{3}{|c|}{ Normal } & \multicolumn{3}{|c|}{ SLE } & \multirow[b]{2}{*}{ Stat } \\
\hline & & Total & Del & Percent & Total & Del & Percent & \\
\hline \multicolumn{9}{|l|}{ Familial } \\
\hline \multirow[t]{3}{*}{ hv3005 } & Female & 26 & 5 & 19 & 32 & 8 & 25 & NS \\
\hline & Male & 22 & 5 & 23 & 0 & 0 & - & $-*$ \\
\hline & Total & 48 & 10 & 21 & 32 & 8 & 25 & $-^{+}$ \\
\hline \multirow[t]{3}{*}{ C4A } & Female & 25 & 6 & 24 & 32 & 18 & 56 & $P=0.03$ \\
\hline & Male & 22 & 6 & 27 & 0 & 0 & - & -* \\
\hline & Total & 47 & 12 & 26 & 32 & 18 & 56 & $-^{\dagger}$ \\
\hline \multicolumn{9}{|l|}{ Population } \\
\hline \multirow[t]{3}{*}{ hv3005 } & Female & 51 & 4 & 8 & 36 & 8 & 22 & $P=0.07$ \\
\hline & Male & 37 & 3 & 8 & 5 & 2 & 40 & $P=0.1$ \\
\hline & Total & 88 & 7 & 8 & 41 & 10 & 24 & $P=0.02$ \\
\hline
\end{tabular}

* Since there were no male SLE patients in these families, a test of association can not be carried out. ${ }^{+}$Since there were no male SLE patients in these families, a test for all subjects (stratified by gender) amounted to the test for females alone, which attained $P=0.03$ for $\mathrm{C} 4 \mathrm{~A}$ and was not significant for hv3005.

this end, 19 additional sporadic cases of SLE and 46 additional healthy unrelated controls were recruited into the study. The results from this new series of additional patients and normals were compared with the data from the previous series by a test for three-way interaction, series (i.e., old or new) by diagnosis (i.e., SLE or normal) by deletion (i.e., presence or absence). A $P$ value of 0.72 was attained. Moreover, the Mantel-Haenszel $\chi^{2}$ (controlling for series) was almost identical to the ordinary Pearson $\chi^{2}$ for association of deletion and diagnosis (10). Thus, it is reasonable to combine the results from both the current series and previous series, and the overall results are given in Table II. As can be seen, analysis of these individuals revealed deletion of the hv3005 genes in 10 patients (24\%) and 7 normals (8\%), resulting in a $P$ value of 0.02 .

Family study of the C4A deletion in SLE. The fourth component of complement is expressed as two isotypes, respectively designated C4A and C4B. Our interest in these isotypes in relation to familial SLE was predicated upon data showing deletion of at least one copy of the C4A genes in $\sim 44 \%$ of white SLE patients, but in only $\sim 13 \%$ of healthy controls (3). It has been suggested that C4A functions mainly in the assembly of C3 convertase on the surface of antigen-antibody complexes, while $\mathrm{C} 4 \mathrm{~B}$ participates in the generation of $\mathrm{C} 3$ convertase on the surface of bacteria. In this context, it is conceivable that the association of $\mathrm{C} 4 \mathrm{~A}$ deficiency with lupus may reflect the affected individual's inability to process immune complexes efficiently, leading to an excess of circulating immune complexes following infections $(2,14)$.

To assess the possibility that $\mathrm{C} 4 \mathrm{~A}$ deletion influences the effect of hv3005 deletion on predisposition to SLE, we analyzed members of the 14 SLE families with respect to C4A RFLP genotypes. Genomic DNA was digested with HindIII and analyzed for hybridization with a fragment from the C4A gene ( 5 ' C4) previously shown to detect 15 - and $26-\mathrm{kb}$ restriction bands, representing the $\mathrm{C} 4 \mathrm{~A}$ and $\mathrm{C} 4 \mathrm{~B}$ genes, respectively (3). In individuals carrying the HLA-B8.C4AQ0.C4B1.HLA-DR3 ex- tended haplotype, which is associated with deletion of most of the C4A gene and all the 21-hydroxylase $(21-\mathrm{OH})$ pseudogene, this probe has been shown to define an $8.5-\mathrm{kb}$ band, representing a C4A-C4B hybrid gene. Thus, individuals with a heterozygous deletion of the $\mathrm{C} 4 \mathrm{~A}$ gene show a $5^{\prime}-\mathrm{C} 4$ restriction profile containing 26-, 15-, and 8.5-kb bands, while a profile limited to the $8.5-\mathrm{kb}$ band demarcates homozygous deletion of the $\mathrm{C} 4 \mathrm{~A}$ gene.

As shown in Table I, C4A deletion was apparent in 18/32 (56\%) patients and in $12 / 47(26 \%)$ healthy family members. Since there were no male patients in these families, standard $\chi^{2}$ testing could not be applied to the analysis of these observations. When only the data obtained on female patients and relatives are analyzed, the frequencies of $\mathrm{C} 4 \mathrm{~A}$ deletion were $18 / 32$ (56\%) for patients and 6/25 (24\%) for normal relatives. Analysis of these latter observations revealed C4A deletion to be significantly more frequent in patients than healthy normals $(P$ $=0.03$ ). C4A genotypes were not examined in unrelated patients and healthy controls as additional genomic DNA for these studies was not available for many individuals.

Family and population studies of the tcr alpha chain constant region RFLP in SLE. Previously, Tebib and co-workers reported an association between a characteristic TCR $\alpha$ chain RFLP and SLE (4). These studies involved analysis of PstIdigested DNA from Caucasian lupus patients using a TCR $\alpha$ chain cDNA, derived from the HPB-MLT $T$ cell line. This probe contains sequences for the leader, $\mathrm{V}$, joining, constant and $3^{\prime}$ untranslated regions (4). Using this probe, 3.0- and 1.3$\mathrm{kb}$ bands were detected in $15 / 31(48 \%)$ unrelated SLE patients, but in only $4 / 34(12 \%)$ unrelated normal controls $(P<0.002)$. When five multiplex families were studied for this polymorphism, members of three families $(60 \%)$ were found to have the disease-associated RFLP. However, in these three families, the putative SLE-associated RFLP was found not only in 6/ $10(60 \%)$ patients, but also in $9 / 20(45 \%)$ healthy relatives. Moreover, the authors reported that the diagnostic $1.3 / 3.0-\mathrm{kb}$ band pair could be detected with a 515-bp RsaI-AvalI fragment encompassing mainly the TCR constant region. These data led them to hypothesize that the "normal" allele represented by a 4.3-kb PstI fragment contains the first two exons of the TCR $\mathrm{C} \alpha$ gene (TCR C $\alpha 1$ and TCR C $\alpha 2$ ), and that the "SLE" allele represented by the $3.0-$ and $1.3-\mathrm{kb}$ bands arises due to an additional Pst1 site in this genomic segment (4).

Based on these observations, DNA samples from the subjects under study were digested with Pst 1 and examined for hybridization with the TCR $\alpha$ chain $\mathrm{C} \alpha 1$ and $\mathrm{C} \alpha 2$ probes. While it was anticipated that $4.3-\mathrm{kb}$ alleles would predominate among controls and that $3.0 / 13-\mathrm{kb}$ alleles would predominate among the patients, our analysis of 10 patients and 6 normal relatives from 5 of our multiplex families revealed that all 16 individuals showed only $4.3-\mathrm{kb}$ bands when studied with the TCR C $\alpha 1$ probe. Similarly, a subsequent analysis of 18 unrelated SLE patients with this probe again revealed only $4.3-\mathrm{kb}$ bands. Moreover, re-analysis of these individuals using the TCR $\alpha$ chain $\mathrm{C} \alpha 2$ probe also revealed the presence of only $4.3-\mathrm{kb}$ bands. Therefore, this analysis did not confirm previous findings suggesting an abnormal prominence of the 3.0/1/3 TCR $\alpha$ chain RFLP in SLE patients.

\section{Discussion}

As a step toward elucidating the genes contributing to SLE susceptibility, we examined members of 14 multicase SLE fami- 


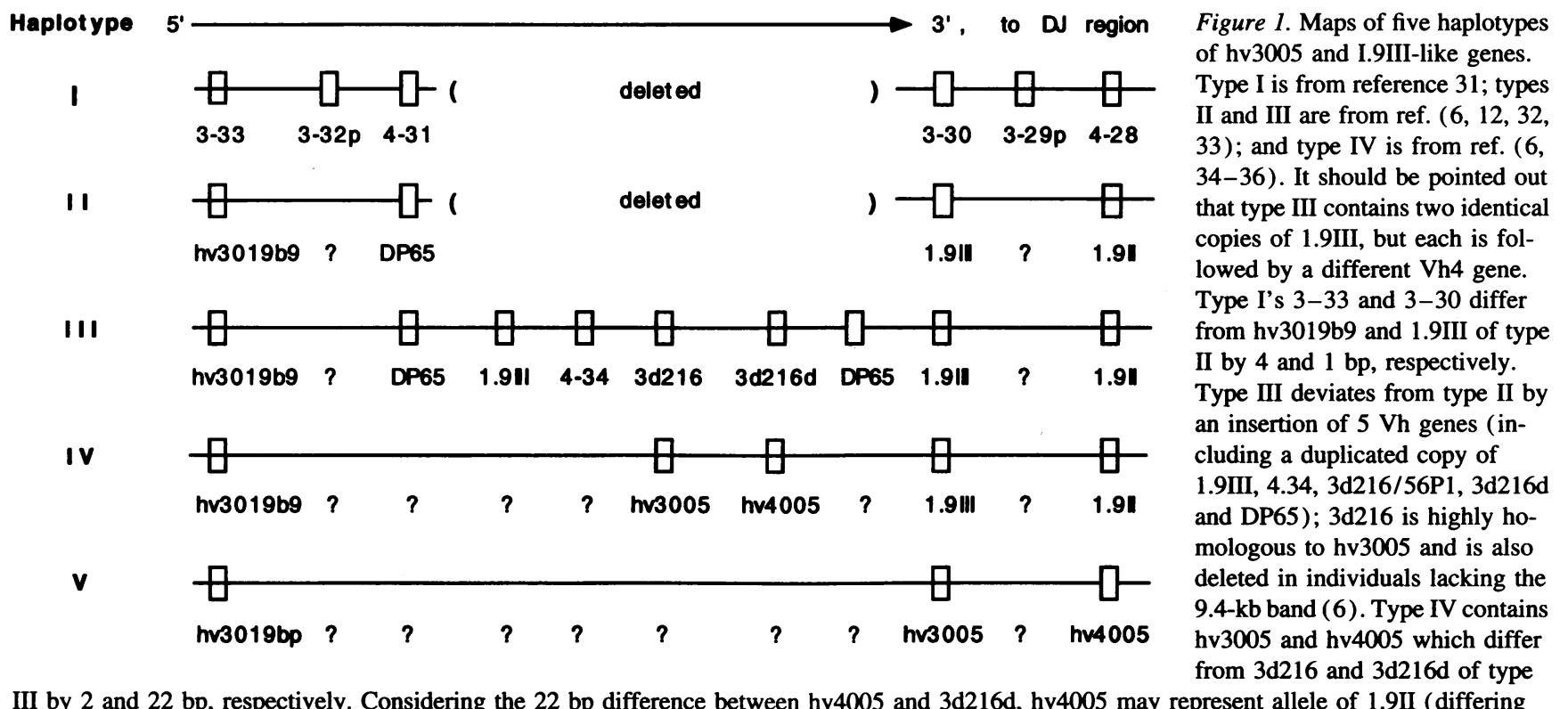

from each other by only $4 \mathrm{bp}$ ), as proposed in type $\mathrm{V}$.

lies, as well as unrelated patients and normal controls, for expression of three previously reported disease-associated RFLPs. Results of the analysis of hv3005/P1 polymorphisms in 41 unrelated patients and 88 healthy controls revealed a significant association between the disease and the complete deletion of the $9.4-\mathrm{kb}$ band $(P=0.02)$. However, the current study failed to detect an association between disease and hv3005 deletion in the SLE patients from the 14 multicase families. In contrast, analyses of the same set of families revealed a significant association of C4A deletion with SLE among the female patients (56 vs. $24 \%$ for healthy female relatives; $P=0.03$ ). In a previous study of C4A genotypes in lupus, Kemp et al. detected a C4A deletion in $\sim 44 \%$ of unrelated white patients and $\sim 13 \%$ of normal controls $(P<0.05)(3)$. It therefore appears that the frequency of $\mathrm{C} 4 \mathrm{~A}$ deletion may differ in healthy individuals from the population versus healthy members of SLE families (13 vs. 26\%). Similarly, C4A deletion may occur less frequently in random cases of SLE $(44 \%)$ than in patients from multicase families $(56 \%)$. In this context, it is noteworthy that the frequency of hv3005 deletion among healthy individuals also increases from $8 \%$ in unrelated individuals to $21 \%$ in familial subjects. Why the disease-associated genotypes occur more frequently in healthy individuals from SLE families than in those from the general population is unknown at this point.

Individuals included in the study were also assessed with respect to their inheritance of a putative disease-associated TCR $\alpha$ chain RFLP. The analysis failed to show any association of the disease with the 3- and 1.3-kb bands, previously suggested as representing the "SLE" allele (4). The discrepancy between the current results and those previously reported with respect to this polymorphism may be due to ethnic difference in the populations analyzed in these two studies.

Extensive analyses of autoantibodies have revealed that certain autoantibodies are found regularly in the normal immune system, and that these autoantibodies are encoded by a restricted set of $\mathrm{Vh}$ genes which constitute the neonatal antibody repertoire (15-21). These findings have led to a "network" hypoth- esis for autoimmune responses, wherein it is suggested that, during early ontogenesis and in the absence of exogenous antigens, autoreactive $\mathrm{V}$ genes are stimulated and selected by certain autoantigens to form the initial antibody repertoire (20, 22-24). Once selected, the V genes interact with each other, to maintain the homeostasis of the antibody repertoire. In addition, some of these $\mathrm{V}$ genes serve as the first line of defense against infectious agents (25-27). According to this hypothesis, the observed association of hv3005 deletion with SLE may be interpreted as implying that hv3005 represents an important autoreactive $\mathrm{V}$ gene and its homozygous deletion may result in generation of an aberrant $B$ cell repertoire, with a consequent abnormal immune response to infection and predisposition of the host to development and/or perpetuation of autoimmune disorders. Alternatively, absence of hv3005 genes may exert its effect on immune response by virtue of altering immune complex clearance. Sequence comparisons reveal hv3005 to be highly homologous to the heavy chain of the SJ2 rheumatoid factor (28) and data from several groups suggest that rheumatoid factors enhance macrophage ingestion and clearance of immune complexes $(29,30)$. Accordingly, deletion of hv3005-like genes may confer susceptibility to SLE by virtue of an effect on the production of rheumatoid factors. This paradigm may be analogous to that proposed for the association between homozygous C4A null alleles and SLE, an observation also ascribed to aberrations in the clearance and solublization of immune complexes (3).

Recently, studies on the hv3005 and 1.9III-like Vh3 genes indicate this $\mathrm{Vh}$ locus to be complex and heterogeneous. As shown in Fig. 1, these data suggest the existence of five hv3005/ 1.9III haplotypes $(6,12,31-36)$. Among these, the haplotype designated as type I contains the 3-33 and 3-30 genes, which differ from the hv3019b9 and 1.9III genes comprising the type II haplotype by 4 and $1 \mathrm{bp}$, respectively $(6,32)$. Type III haplotype is, in turn, distinguished from type II by an insertion of $5 \mathrm{Vh}$ genes (including a duplicated copy of 1.9III, 4.34, $3 \mathrm{~d} 216 / 56 \mathrm{P} 1,3 \mathrm{~d} 216 \mathrm{~d}$ and DP65) $(12,32) ; 3 \mathrm{~d} 216$ is highly 
homologous to hv3005 and is also deleted in individuals lacking the 9.4-kb band (6). The type IV and V haplotypes contain the hv3005 and hv4005 genes which differ from $3 d 216$ and 3d216d of type III by 2 and $22 \mathrm{bp}$, respectively (34), and thus may exist as alleles of $3 \mathrm{~d} 216$ and $3 \mathrm{~d} 216 \mathrm{~d}$ in type III. Alternatively, hv3005 and hv4005 may represent alleles of $1.9 \mathrm{III}$ and $1.9 \mathrm{II}$ in type V. Among these five haplotypes, types I and II lack all hv3005-like genes, including hv3005 and 3d216. Importantly, deletion of not only $3 \mathrm{~d} 216$, but also four other Vh genes, distinguishes types I and II from type III haplotype. Thus, the detection of hv3005 deletion in certain individuals may also be associated with deletion of four additional $\mathrm{Vh}$ genes, a possibility that might be of significance in relation to the putative association of the hv3005 deletion with SLE susceptibility. Moreover the hv3019b9 and 1.9III genes (type II haplotype), but not the 3-33 and 3-30 genes (type I) have been shown to be expressed in fetal liver $(31,37,38)$. It is therefore possible that these hv3005-deleted haplotypes differ with regards to the extent to which they confer risk for SLE.

Although hv3005 deletion was associated with SLE in unrelated patients, the current study failed to detect an association between hv3005 deletion and SLE in familial cases. While the basis for this discrepancy is unclear, it is possible that in some individuals the critical function(s) of hv3005-like genes can be compensated by other autoreactive Vh genes. As such, the induction of SLE would require additional genetic hit(s) which deletes both copies of one or more of other physiologically important autoreactive $\mathrm{Vh}$ genes. By contrast, $\mathrm{C} 4 \mathrm{~A}$ is a single copy gene, and the product of the homologous $\mathrm{C} 4 \mathrm{~B}$ gene is less efficient in binding to immune complexes and in inhibiting immune precipitation. Thus, unlike hv3005, deletion of even only one copy of C4A gene may confer disease susceptibility. Taken together, the current data suggest that C4A deletion confers a strong genetic risk for SLE, while hv3005 deletion confers a weak risk for expression of this disease.

In evaluating these data, another possibility for consideration is that the influence of a weak disease susceptibility gene may be obscured by the effects of a strong disease susceptibility gene. In other words, the contribution of hv3005 to SLE susceptibility may be masked by the strong impact of C4A deletion and female sex. In this context, it is noteworthy that C4A deletions were detected in patients from 13/14 multicase SLE families, and in the single family not manifesting this defect (i.e., family 2), 3/3 patients showed hv3005 deletion, while the one healthy relative did not (Table I). Similarly, hv3005 deletion, while not common in the familial cases of SLE, was detected in $2 / 5(40 \%)$ unrelated male patients. These data raise the possibility that the influence of hv3005 deletion on disease predisposition is more easily detected in male than in female SLE patients and in SLE patients lacking C4A deletions.

In summary, the results of the current study on both familial and sporadic cases of SLE confirm the strong association between C4A deletion and SLE that has been reported in studies of unrelated patients. By contrast, while the findings confirm the previously detected association between hv3005 deletion and sporadic SLE, the data fail to support this association in SLE patients from multicase families. The results also suggest that C4A deletion and gender are major factors in susceptibility to SLE, while hv3005 deletion plays a lesser role. Together, these data highlight the value of both family and population studies in identifying SLE-susceptibility genes. Analyses of multiplex families enable one to delineate the relative importance of candidate genes in SLE, and to determine how they may interact to enhance disease susceptibility.

\section{Acknowledgments}

The authors thank Dr. Chaplin for his 5'-C4 probe. Funding for this research is supported in part by grants AI-32243, AR-25443, AR-40770, and RR-00833 from the National Institutes of Health, by grant MA10730 from the Medical Research Council of Canada, by grant 7-28886 from the Arthritis Society of Canada.

\section{References}

1. Woods, V. L., Jr. 1993. Pathogenesis of systemic lupus erythematosus. In Textbook of Rheumatology. W. N. Kelley, E. D. Harris, Jr., S. Ruddy, and C. B. Sledge, editors. W. B. Saunders, Philadelphia; PA. 999-1016.

2. Reveille, J. D. 1991. The molecular genetics of systemic lupus erythematosus and Sjogren's syndrome. Curr. Opin. Rheumatol. 3:722-730.

3. Kemp, M. E., J. P. Atkinson, V. M. Skanes, R. P. Levine, and D. D. Chaplin. 1987. Deletion of C4A genes in patients with systemic lupus erythematosus. Arthritis Rheum. 30:1015-1022.

4. Tebib, J. G., J. Alcocer-Varela, D. Alarcon-Segovia, and P. H. Schur. 1990. Association between a $\mathrm{T}$ cell receptor restriction fragment length polymorphism and systemic lupus erythematosus. J. Clin. Invest. 86:1961-1967.

5. Yang, P.-M., N. J. Olsen, K. A. Siminovitch, T. Olee, F. Kozin, D. A. Carson, and P. P. Chen. 1990. Possible deletion of a developmentally regulated Vh gene in autoimmune disease. Proc. Natl. Acad. Sci. USA. 87:7907-7911.

6. Olee, T., P.-M. Yang, K. A. Siminovitch, N. J. Olsen, J. Hillson, J. Wu, F. Kozin, D. A. Carson, and P. P. Chen. 1991. Molecular basis of an autoantibodyassociated restriction fragment length polymorphism that confers susceptibility to autoimmune diseases. J. Clin. Invest. 88:193-203.

7. Tan, E. M., A. S. Cohen, J. F. Fries, A. T. Masi, D. J. McShane, N. F. Rothfield, J. G. Schaller, N. Talal, and R. J. Winchester. 1982. The 1982 revised criteria for the classification of systemic lupus erythematosus. Arthritis Rheum. 25:1271-1277.

8. Yoshikoi, Y., S. Clark, S. Taylor, V. Sohn, B. Wilson, M. Minden, and T. Mak. 1985. Organization and sequences of the variable, joining and constant region genes of the human $\mathrm{T}$ cell receptor alpha chain. Nature (Lond.). 316:837840.

9. Lee, W.-H., R. Bookstein, F. Hong, L.-J. Young, J.-Y. Shew, and Y.-H. P. Lee. 1987. Human retinoblastoma susceptibility gene: Cloning, identification, and sequence. Science (Wash. DC). 235:1394-1399.

10. Bishop, Y. M. M., S. E. Fienberg, and P. W. Holland. 1975. Discrete Multivariate Analysis. The MIT Press, Cambridge, MA.

11. Kahn, H. A., and C. T. Sempos. 1989. Adjustment of Data Without Use of Multivariate Models. In Statistical Methods in Epidemiology. Oxford University Press, New York. 85-136.

12. Sasso, E. H., K. W. Van Dijk, A. Bull, S. M. Van der Maarel, and E. C. B. Milner. 1992. $\mathrm{V}_{\mathrm{H}}$ genes in tandem array comprise a repeated germline motif. $J$. Immunol. 149:1230-1236.

13. Hochberg, M. C. 1990. Systemic lupus erythematosus. Rheum. Dis. Clin. No. Am. 16:617-639.

14. Gatenby, P. A. 1991. The role of complement in the aetiopathogenesis of systemic lupus erythematosus. Autoimmunity. 11:61-66.

15. Chen, P. P., M.-F. Liu, S. Sinha, and D. A. Carson. 1988. A 16/6 idiotype positive anti-DNA antibody is encoded by a conserved Vh gene with no somatic mutation. Arthritis Rheum. 31:1429-1431.

16. Chen, P. P., S. Fong, F. Goni, G. J. Silverman, R. I. Fox, M.-F. Liu, B. Frangione, and D. A. Carson. 1988. Cross-reacting idiotypes on cryoprecipitating rheumatoid factor. Springer Semin. Immunopathol. 10:35-55.

17. Siminovitch, K. A., V. Misener, P. C. Kwong, Q-L. Song, and P. P. Chen. 1989. A natural autoantibody is encoded by germline heavy and lambda light chain variable region genes without somatic mutation. J. Clin. Invest. 84:16751678.

18. Casali, P., and A. L. Notkins. 1989. Probing the human B-cell repertoire with EBV: polyreactive antibodies and CD5+ B lymphocytes. Annu. Rev. Immunol. 7:513-535.

19. Schroeder, H. W., Jr. and J. Y. Wang. 1990. Preferential utilization of conserved immunoglobulin heavy chain variable gene segments during human fetal life. Proc. Natl. Acad. Sci. USA. 87:6146-6150.

20. Chen, P. P., N. J. Olsen, P-M Yang, R. W. Soto-Gil, T. Olee, K. A. Siminovitch, and D. A. Carson. 1990. From human autoantibodies to fetal antibody repertoire to B cell malignancy: It's a small world after all. Int. Rev. Immunol. 5:239-251. 
21. Siminovitch, K. A., and P. P. Chen. 1990. The biologic significance of human natural autoimmune responses: relationship to the germline, early immune and malignant B cell variable gene repertoire. Intern. Rev. Immunol. 5:265-277.

22. Coutinho, A. 1989. Beyond clonal selection and network. Immunol. Rev. 110:63-87.

23. Weill, J.-C., and C.-A. Reynaud. 1992. Early B-cell development in chickens, sheep and rabbits. Curr. Opinion Immunol. 4:177-180.

24. von Boehmer, H. 1994. Positive selection of lymphocytes. Cell. 76:219 228.

25. Naparstek, Y., J. Andre-Schwartz, T. Manser, L. J. Wysocki, L. Breitman, B. D. Stollar, M. Gefter, and R. S. Schwartz. 1986. A single germline VH gene segment of normal A/J mice encodes autoantibodies characteristic of systemic lupus erythematosus. J. Exp. Med. 164:614-626.

26. Huang, D.-F., T. Olee, Y. Masuho, Y. Matsumoto, D. A. Carson, and P. P. Chen. 1992. Sequence analyses of three IgG anti-virus antibodies revea their utilization of autoantibody-related $\mathrm{Ig} \mathrm{Vh}$ genes, but not $\mathrm{V} \lambda$ genes. J. Clin Invest. 90:2197-2208.

27. Schwartz, R. S., and B. D. Stollar. 1994. Heavy-chain directed B-cell maturation: continuous clonal selection beginning at the pre-B cell stage. Immunol. Today. 15:27-32.

28. Pascual, V., I. Randen, K. Thompson, M. Sioud, O. Forre, J. Natvig, and J. D. Capra. 1990. The complete nucleotide sequences of the heavy chain variable regions of six monospecific rheumatoid factors derived from Epstein-Barr virustransformed B cells isolated from the synovial tissue of patients with rheumatoid arthritis. J. Clin. Invest. 86:1320-1328.

29. Carson, D. A., P. P. Chen, R. I. Fox, T. J. Kipps, F. Jirik, R. D. Goldfien G. Silverman, V. Radoux, and S. Fong. 1987. Rheumatoid factors and immune networks. Annu. Rev. Immunol. 5:109-126.

30. Chen, P. P., and D. A. Carson. 1994. New insights on the physiological and pathological rheumatoid factors in humans. In Autoimmunity: Physiology and Disease. A. Coutinho and M. D. Kazatchkine, editors. Wiley-Liss, Inc., New York. 247-266.

31. Matsuda, F., E. K. Shin, H. Nagaoka, R. Matsumura, M. Haino, Y. Fukita, S. Takaishi, T. Imai, J. H. Riley, R. Anand, E. Soeda, and T. Honjo. 1993. Structure and physical map of 64 variable segments in the 3' 0.8 -megabase region of the human immunoglobulin heavy-chain locus. Nature Genet. 3:88-94.

32. Walter, G., I. M. Tomlinson, G. P. Cook, G. Winter, T. H. Rabbits, and P. H. Dear. 1993. HAPPY mapping of a YAC reveals alternative haplotypes in the human immunoglobulin $\mathrm{V}_{\mathrm{H}}$ locus. Nucleic Acids Res. 21:4524-4529.

33. Berman, J. E., S. J. Mellis, R. Pollock, C. L. Smith, H. Suh, B. Heinke C. Kowal, U. Surti, L. Chess, C. R. Cantor, and F. W. Alt. 1988. Content and organization of the human $I g V_{H}$ locus: definition of three new $V_{H}$ families and linkage to the Ig $C_{H}$ locus. EMBO (Eur. Mol. Biol. Organ.) J. 7:727-738.

34. Van Dijk, K. W., L. A. Milner, E. H. Sasso, and E. C. B. Milner. 1992 Chromosomal organization of the heavy chain variable region gene segments comprising the human fetal antibody repertoire. Proc. Natl. Acad. Sci. USA 89:10430-10434.

35. Chen, P. P. 1990. Structural analyses of human developmentally regulated Vh3 genes. Scand. J. Immunol. 31:257-267.

36. Chen, P. P., and P-M. Yang. 1990. A segment of the human Vh gene locus is duplicated. Scand. J. Immunol. 31:593-599.

37. Nickerson, K. G., J. Berman, E. Glickman, L. Chess, and F. W. Alt. 1989. Early human IgH gene assembly in Epstein-Barr virus-transformed fetal B cell lines. Preferential utilization of the most JH-proximal D segment (DQ52) and two unusual VH-related rearrangements. J. Exp. Med. 169:1391-1403.

38. Hillson, J. L., I. R. Oppliger, E. H. Sasso, E. C. B. Milner, and M. H Wener. 1992. Emerging human B cell repertoire: Influence of developmental stage and interindividual variation. J. Immunol. 149:3741-3752. 